\title{
THE EFFECTS OF ETHICAL CLIMATE TYPES ON JOB SATISFACTION: THE CASE OF TOURISM INDUSTRY ${ }^{*}$
}

\author{
Metin KAPLAN** \\ Adem ÖĞÜT*** \\ Selcuk KARAYEL $* * * *$ \\ İbrahim ILLHAN*****
}

\begin{abstract}
This research aims to analyse the relationship between ethical climate types and job satisfaction in tourism industry. To achive this objective, an empirical study was conducted on 165 hotel business employees in four-star and five-star hotels licensed by the Culture and Tourism Ministry in the city of Nevsehir, Turkey. Results show that caring positively and significantly correlated with job satisfaction. According to correlation analysis, no significant relationships were found between other four dimensions of ethical climate such as law and code, rules, instrumental, and independence and job satisfaction. Regression analysis results showed that caring could explain differences in job satisfaction. Implications of the findings are discussed and avenues for future research are offered.
\end{abstract}

Keywords: Ethical climate, job satisfaction, organizational behavior, tourism industry, hotel businesses.

\footnotetext{
* This study titled "The effects of ethical climate types on job satisfaction: The case of tourism industry" is the extended version of the paper presented in Rome Multidisiplinary Conference, Oct 31-Nov 3, 2011, Rome, Italy.

** Assist.Prof.Dr., Nevsehir University, Tourism Business and Hotel Management Department, NEVŞEHİR, mkaplan@nevsehir.edu.tr

*** Prof.Dr., Selcuk University, Departmant of Business Administration, KONYA, ogut.adem@gmail.com

****Assist.Prof.Dr., Necmettin Erbakan University, Departmant of Business Administration, KONYA, skarayel@konya.edu.tr

*****Assist.Prof.Dr., Nevsehir University, Tourism Faculty, NEVSEHIR, ibrahim@nevsehir.edu.tr
} 


\section{$\ddot{O} z$}

\section{Etiksel İklimin İș Tatmini Üzerindeki Etkisi: Turizm Endüstrisi Örneği"}

$\mathrm{Bu}$ araştırmanın amacı, turizm endüstrisinde etiksel iklim boyutları ile iş tatmini arasındaki ilişkiyi analiz etmektir. Bu hedefe ulşamak için, Nevşehir ilindiki Kültür ve Turizm Bakanlığı belgeli dört ve beş yıldızlı otellerde çalışan 165 işgörene üzerinde görgül bir araştırma yürütülmüştür. Araştırma sonuçlarına göre, başkalarının iyiliğini isteme boyutu ile iş tatmini arasında pozitif yönlü ve anlamlı bir ilişki tespit edilirken, diğer dört boyut olan kanun ve kod, kurallar, araçsallık ve bağımsızlık ile iş tatmini arasında anlamlı bir ilişki olmadığı bulgusuna ulaşılmıştır. Regresyon analizi sonuçlarına göre, başkalarının iyiliğini isteme boyutunun iş tatminini üzerinde açıklayıcı etkiye sahip olduğu ortaya konmuştur. Araştırma bulguları tartışılmış ve araştırma alanları önerilmiştir.

Anahtar Sözcükler: Etiksel iklim, iş tatmini, örgütsel davranış, turizm endüstrisi, otel işletmeleri.

\section{INTRODUCTION}

One of the most important factors in tourism and hospitality organizations is human being in terms of service quality, customer satisfaction and commitment, competitive advantage and organizational performance. This belief is supported by the notion that emphasizes the critical importance of human resources for organizations. That view is further supported by many theories, models and empirical studies on service and tourism management literature (Kusluvan et al., 2010: 171). Satisfaction of employees working in hotel businesses may produce positive results such as increase in productivity, creation of competitive advantage, reduction of optional labor turnover rate, resultant customer satisfaction and so forth.

The employee satisfaction is defined as "the positive emotional state that one felt after evaluating one's own job and work experience" (Kusluvan, Kusluvan, 2003: 183); and the ethical climate is defined as "the shared perceptions of what is ethically correct behavior and how ethical issues should be handled" (Victor, Cullen, 1988: 101). Ethical climate has a significant impact on individual behavior and on the organization as a whole (Kaplan, 2010: 10). In essence, ethical climate is examined most commonly using five dimensions such as caring, laws and codes, rules, instrumentalism and independence (Ogut, Kaplan, 2010: 894). It can be said that as caring, laws and codes, rules and independence climate type perceptions of these dimensions increase, job satisfaction may also increase. On the other hand, as instrumentalism climate type perceptions increase, job satisfaction may 
decrease. The results of the researches analyzing the relationship between the ethical climate and the job satisfaction are presented below:

Deshpande (1996) classified the aspects of the ethical climate as professionalism, caring, rules, instrumentalism, productivity and he also classified the job satisfaction in an independent way as promotion, wage satisfaction, workmates satisfaction, work satisfaction and total job satisfaction in a survey conducted with 252 mid level managers at a large nonprofit charity organization. The survey results indicated the following points: None of the climate types could affect the wage satisfaction and the professional climate type could affect the promotion, manager and work satisfactions. Also he further found that instrumentalism climate type could affect the job satisfaction, promotion, workmates, manager satisfaction in a negative direction and the types of climate such as rules, productivity and independence couldn't affect any aspects of job satisfaction meaningfully. Although Koh and Boo (2001) stated that there wasn't any meaningful relationship between the climate type based on philanthropic and the job satisfaction, they also pointed out that there was a positive and meaningful relationship between the ethical climate based on principles and the job satisfaction in a survey conducted among the managers in Singapore. Schwepker Jr. (2001) pointed out that a positive and meaningful relationship existed between the perceptions of the ethical climate and total work satisfaction (wage, promotion, manager, policies and satisfaction from the customers). Suar and Khuntia (2004) stated that the professional climate and well wishes for the others (caring) could positively affect the external and internal job satisfaction in a survey conducted among the mid level managers at the private and public sectors. Schminke et al.,(2005) pointed out that there was a positive and meaningful relationship between the caring and the rules, the perceptions of the ethical climate and job satisfaction. Schwepker Jr. and Hartline (2005) stated that the perceptions of the ethical climate could increase the job satisfaction in a survey conducted among the hotel employees. Mulki et al., (2006) pointed out that a positive direction and meaningful relationship existed between the perceptions of the ethical climate and the job satisfaction and the perceptions of the ethical climate could be the determinant factor over the job satisfaction of the sales personel in a survey conducted among the pharmacy employees in the USA. Aydemir (2007) classified the aspects of the ethical climate as altruism, prescriptivism, instrumentalism, effectuality and independency in a survey conducted among the employees working at nine private and public corporations dealing with different sectors in Bilecik (Turkey) and its surroundings and added that the altruism and the prescriptivism, the types of climate had a meaningful impact over the general job satisfaction. He also stated that the instrumentalism aspect had a negative direction and meaningful impact over the general job satisfaction. Kim and Miller (2008) stated that while the types of climate such as the self interest and 
the efficiency could affect the job satisfaction in a negative direction, the other types of the ethical climate could affect the job satisfaction in a positive direction. Tsai and Huang (2008) stated that there was a positive relationship between the climate type based on philanthropic and wage satisfaction, job satisfaction and the total job satisfaction. Furthermore, they pointed out that a positive direction and meaningful relationship existed between the independent climate perception and satisfaction from the managers and total job satisfaction. On the other hand, it was indicated by the same study that a positive and meaningful relationship between the rules ethical climate and manager satisfaction, workmates satisfaction, payment satisfaction and the total satisfaction. On the contrary, they expressed that there was a negative and a meaningful relationship between the instrumentalism climate type and promotion satisfaction and total job satisfaction. Nonetheless, they couldn't find out a relationship between the laws and codes ethical climate perceptions and job satisfaction in a survey conducted among the nurses in Taiwan. Elçi and Alpkan (2009) analyzed the ethical climate in nine aspects and stated that the self interest climate affected job satisfaction in a negative way while the benefit of team, social responsibility and the laws and the codes ethical climate affected the job satisfaction in a positive way in a survey conducted among the employees and the managers from telecommunication industry.

The main goal of our research is based on the question of "at what level are the perceptions of ethical climate effective on providing job satisfaction of employees working in hotel businesses". In other words, the aim of the study is to analyze the relationship between the perceptions of ethical climate and overall job satisfaction of the staff employed in four and five star hotels in Nevşehir. In this context, relatedness between perceptions of ethical climate and job satisfaction will be examined in a different culture and different servicebased sector and recommendations will be presented to managers of hotel businesses.

\section{ETHICAL CLIMATE}

The ethical climate is a component of the general organizational climate and has been described as 'the shared perceptions of what ethically correct behaviour is and how ethical issues should be handled' (Elçi, Alpkan, 2009: 298). Ethical climate is a concept that describes the shared perception of organizational norms, values and behaviour (Rasmussen et al., 2003: 85). A firm's ethical climate refers to the prevailing attitudes about the firm's standards concerning appropriate conduct within the firm (Kelley, Dorsch, 1991: 56) and reflects employee perceptions of morally appropriate actions and policies observed in the workplace (Lopez et al., 2009: 595). Ethical work climate is a 
holistic construct which encompasses the catalogue of organizational sociomoral factors (Ruppel and Harrington, 2000: 314).

Victor and Cullen's (1988) ethical decision making framework describes theoretical ethical climates that are based on two dimensions: ethical criterion and locus of analysis (Weber, Seger, 2002: 72). Figure.1 shows ethical climate types according to a two-dimensional typology. The first dimension represents the ethical criteria used for decision-making inside an organization. 'Egoism' is characterized by decisions intended to maximize self-interest, 'benevolence' is characterized by decisions that aim to maximize joint interest, while 'principle' is characterized by decisions which adhere to rules, laws, and standards in the normative expectations of a social unit (Kim, Miller, 2008: 942-943). The second dimension represents the locus of analysis used as a reference point in ethical decisions (Weber, 1995: 512). At the individual level, the ethical climate of the organization supports an individual-level source for normative standards regarding ethical reasoning. The local level is supported by organizational norms favoring reference groups within the organization itself. The cosmopolitan ethical climate is supported by norms favoring external sources for ethical reasoning (Barnett, Vaicys, 2000: 352).

Figure 1. Victor and Cullen's Ethical Climate Matrix

\begin{tabular}{|c|c|c|c|c|}
\hline & & \multicolumn{3}{|c|}{ Locus of Analysis } \\
\hline & & Individual & Local & Cosmopolitan \\
\hline \multirow{3}{*}{ 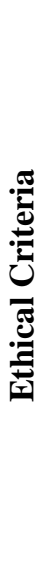 } & 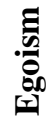 & $\begin{array}{l}\text { SELF-INTEREST* } \\
\text { Instrumental } * *\end{array}$ & $\begin{array}{l}\text { COMPANY PROFIT } \\
\text { Instrumental }\end{array}$ & EFFICIENCY \\
\hline & 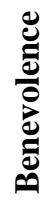 & $\begin{array}{l}\text { FRIENDSHIP } \\
\text { Caring }\end{array}$ & $\begin{array}{l}\text { TEAM INTEREST } \\
\text { Caring }\end{array}$ & $\begin{array}{c}\text { SOCIAL } \\
\text { RESPONSIBILITY }\end{array}$ \\
\hline & 尝 & $\begin{array}{l}\text { PERSONAL } \\
\text { MORALITY } \\
\text { Independence }\end{array}$ & $\begin{array}{c}\text { COMPANY RULES } \\
\text { AND PROCEDURE } \\
\text { Rules }\end{array}$ & $\begin{array}{c}\text { LAWS AND } \\
\text { PROFESSIONAL } \\
\text { CODES } \\
\text { Law and Code }\end{array}$ \\
\hline
\end{tabular}

* Theoretical strata of ethical climate

** Victor and Cullen's five common empirical dimensions are found in italics Source: Victor, Cullen, 1988, 104; Malloy, Agarwal, 2003, 226. 
As shown in Figure 1, a firm's ethical climate can be characterized in terms of five theoretically based and empirically supported dimensions: Caring, law and code, rules, instrumentalism, and independence (Victor, Cullen, 1988: 111-113). The dimensions are defined as follows:

Caring: A caring climate is utilitarian based where employees have a sincere interest in the well being of others inside and outside the organization (Deshpande et al., 2000: 212) and pertains to displays of kindness toward the employees, the firm, and the world (Kelley, Dorsch, 1991: 56). At work, caring climate reflects concern for all organizational stakeholders affected by their decisions (Shapira-Lishcinsky, Rosenblatt, 2009: 719). Studies assessing an employee's preferred work climate most frequently indicate favor for a caring climate (Martin, Cullen, 2006: 179).

Law and Codes: Employees in a law and code ethical climate are expected to adhere strictly to the codes and regulations of their profession or government (Wimbush et al., 1997: 68). Organizations guided by law and codes accommodated external standards and principles in decision making (Suar, Khuntia, 2004: 12). Whether public or private sector employees "...perform their duties and functions efficiently, effectively and with integrity, in accordiance with laws or administrative policies" (Huberts et al., 2008: 241).

Rules: In rules ethical work climate, the principles employed are company based (i.e. company policies, procedures, rules, norms) (Wyld, Jones, 1997: 467). Employees are expected to adhere precisely to the rules and imperatives of their organization or departments (Erben, Güneşer, 2008: 959). Organizational decisions are guided by a set of local rules or standards such as codes of conduct (Tsai, Huang, 2008: 567). Many organizations aim to guide employees' behavior through formal organizational value statements, mission statements, credos, policies and formal codes of ethical conduct (Trevino, Nelson, 2004: 240).

Instrumentalism: The instrumental climate involves the egoistic criterion and is primarily based on the maximization of self-interest (Tsai, Huang, 2008: 567). In an instrumental climate, employees look out for their own self interest (Deshpande et al., 2000: 212), first and foremost, even to the exclusion of interest of others who may be affected by their decisions (Wimbush et al., 1997: 68). Actors perceiving an instrumental ethical climate see their organizational unit as having norms and expectations that encourage ethical decision-making from an egoistic perspective (Martin, Cullen, 2006: 178).

Independence: This dimension concerns the individual's personal rules of acceptable behavior (Kelley, Dorsch, 1991: 56). In an independent climate, 
individual standard of moral judgment provides the criteria for decision making (Suar, Khuntia, 2004: 12).

Ethical climate has various functions in organizations. Perceptions of ethical climates increase affective commitment (Tsai, Huang, 2008), achievement level of dealing with ethical issues (Bartels et al., 1998), organizational citizenship behaviour (Elçi, 2005), job satisfaction (Elçi, Alpkan, 2009), supervisory trust (Mulki et al., 2006) and performance (Weeks et al., 2004) while decreasing intent to leave (Schwepker Jr., 2001), and role conflict (Schwepker Jr., Hartline, 2005). In this study, we focused on job satisfaction.

\section{JOB SATISFACTION}

A general definition of job satisfaction is viewed as "a pleasurable or positive emotional state resulting from the appraisal of one's job or job experiences" (Vandenabeele, 2009: 14). Another definition regarding job satisfaction is "the degree to which employees have a positive affective orientation toward employment by the organization" (Buchko et al., 1998: 111).

Job satisfaction is believed to be an attitude reflecting how well people like or dislike their job (Mulki et al., 2006: 20) and it is determined by policies and supervision, both factors influencing a firm's ethical climate. Policies and supervisory direction may help eliminate ambiguity on the job related to handling ethical situations (Schwepker Jr., 2001: 41). A conflict between ethical values of the employee and the organization's ethical climate will lead to a lower level of job satisfaction (Koh, Boo, 2001: 313). On the other hand, the more the employees have ethical climate perceptions, the more they are satisfied with their job.

Job satisfaction can be measured in terms of satisfaction with pay, promotion, coworkers, supervision and work or an overall rating of satisfaction. An overall measure is generally taken using the respondents' general perception of how satisfied they are with their job (Mulki et al., 2006: 20). In this study, an overall measure of job satisfaction is used. tested:

In the light of some previous researches, the following hypothesis were 
H1: There is a positive relationship between caring and job satisfaction.

H2: There is a positive relationship between law and code and job satisfaction.

H3: There is a positive relationship between rules and job satisfaction.

H4: There is a negative relationship between instrumentalism and job satisfaction.

H5: There is a positive relationship between independence and job satisfaction.

\section{MEASURES}

Job satisfaction was designated as the dependent variable in this study, while ethical climate types (caring, law and code, rules, instrumentalism and independence) were considered as the independent variables. To measure ethical climate types, the 26 items Ethical Climate Questionnaire (ECQ) developed by Victor and Cullen (1988) was used. The items were classified in terms of the five dimensions of caring, law and code, rules, instrumentalism and independence. Participants responded on a 5-point Likert-type scale dictating to the extent which they agreed with each statement as it reflected their present work environment $(1=$ strongly disagree, $5=$ strongly agree $)$. Cronbach's alphas were as follows: 0.82 for caring, 0.87 for law and code, 0.88 for rules, 0.72 for instrumental and 0.76 for independence.

On the other hand, job satisfaction was measured with short form of Minnesota Satisfaction Questionnaire (MSQ), 20 items 5-point Likert scale ( $1=$ strongly disagree, $5=$ strongly agree). The scale showed adequate reliability. The Cronbach's alpha coefficient was 0.85 . In general, a value of 0.70 in the Cronbach's alpha is considered adequate in order to ensure reliability of the internal consistency of a scale (Nunnally, 1978).

\section{SAMPLE}

The sampling is from employees in four (15) and five-star (5) hotels licensed by the Tourism Ministry in the city of Nevsehir, Turkey. Participants work in front offices, food and beverage, and storey services departments of these hotels. Because of unknown number of employeed personnel in hotels, quata sampling (a quota sample a type of non-probability sample in which the 
The Effects of Ethical Climate Types on Job Satisfaction:

The Case of Tourism Industry

researcher selects people according to some fixed quota) is taken as a basic method that subjects are conveniently chosen from targeted groups (Sekaran, 2003: 280). The researcher would then have to decide how many respondents are to be selected in each category. There are two main possibilities: equal numbers in each category, or numbers proportional to incidence in the population (Blaikie, 2001: 205). In this frame, we decided to distribute 15 questionnaires for each hotel. Interviewers were recruited to distribute to 300 subjects. In total 168 employees responded to the survey. Of the employees who responded, 165 provided useable questionnaires on all study variables for a response rate of 55.0 per cent. This rate is an acceptable response rate for this kind of study (Lewin et al., 1995).

Table 1. Demographic Characteristics of Sample

\begin{tabular}{|c|c|c|c|c|c|}
\hline Characteristics & f & $(\%)$ & Characteristics & f & $(\%)$ \\
\hline Gender & & & Education Level of Participants & & \\
\hline Male & 112 & 67.9 & Primary school & 47 & 28.5 \\
\hline Female & 53 & 32.1 & Secondary school & 78 & 47.3 \\
\hline & & & High school & 25 & 15.2 \\
\hline Status of a person & & & Bachelor' or PhD & 15 & 9.0 \\
\hline Married & 110 & 66.7 & & & \\
\hline Single & 55 & 33.3 & Hotel Category & & \\
\hline & & & Five-star & 60 & 36.4 \\
\hline Age & & & Four-star & 105 & 63.6 \\
\hline Less than 25 & 44 & 26.6 & & & \\
\hline $26-30$ & 81 & 49.1 & Worked Department & & \\
\hline $31-40$ & 25 & 15.2 & Front office & 50 & 30.3 \\
\hline 41 or more & 15 & 9.1 & Food and beverage & 59 & 35.8 \\
\hline & & & Storey service & 56 & 33.9 \\
\hline Tourism education & & & & & \\
\hline Yes & 95 & 57.6 & Job Experience (number of & & \\
\hline No & 70 & 42.4 & years) & & \\
\hline & & & Less than 1 & 36 & 21.8 \\
\hline Position & & & $1-3$ & 55 & 33.3 \\
\hline Department Manager & 12 & 7.3 & $4-6$ & 32 & 19.4 \\
\hline Chief & 26 & 15.8 & $7-9$ & 18 & 10.9 \\
\hline Employee & 127 & 77.0 & 10 or more & 24 & 14.5 \\
\hline
\end{tabular}

The sample consisted of 32.1 percent of females and 67.9 percent of males. 66.7 percent of the respondents were married and 33.3 percent were single. 49.1 percent of the respondents were 26-30 years old. In terms of educational levels, $28.5 \%$ of the respondents had graduated from primary school, $47.3 \%$ from secondary school, $15.2 \%$ from high school, $9.0 \%$ held 
Bachelor's or PhD. Furthermore, more than half of the participants completed the tourism and hotel management training (57.6\%). Respondents held a variety of positions in hotel businesses including middle managers $(23.1 \%)$ and employees (77.0\%). When star classifications of the hotels are taken into consideration, it is seen that the participants to the survey are employed in four star hotels (63.6\%) and five star hotels (36.4\%). 33.3\% of the respondents had 1-3 years of job experience in the present hotels. 30.3 percent of the respondents worked in front office, 35.8 percent of the respondents worked in food and bevarage, 33.9 percent of the respondents worked in storey service. 7.3 percent of the respondents were departmant manager, 15.8 percent were chief and 77.0 percent were employee.

\section{RESEARCH FINDINGS AND DISCUSSION}

Table 2 reports means, standard deviations, correlations among variables, and cronbach's alpha coefficients.

Table 2. Descriptive Statistics and Inter-Correlations Among Study Variables

\begin{tabular}{|l|r|r|r|r|r|r|r|r|}
\hline & Mean & Std. Dev. & \multicolumn{1}{|c|}{ 1 } & \multicolumn{1}{|c|}{ 2 } & \multicolumn{1}{|c|}{ 3 } & $\mathbf{4}$ & $\mathbf{5}$ & 6 \\
\hline 1. Caring & 3,46 & 0,74 & $(0,82)$ & & & & & \\
\hline 2. Law and code & 3,38 & 1,03 &, $264^{* *}$ & $(0,87)$ & & & & \\
\hline 3. Rules & 3,15 & 1,08 &, $255^{* *}$ &, 109 & $(0,88)$ & & & \\
\hline 4. Instrumental & 3,19 & 0,63 &,- 023 &,- 082 &, 046 & $(0,72)$ & & \\
\hline 5. Independence & 3,26 & 0,77 &, $222^{* *}$ &,- 123 &, 149 &, $251^{* *}$ & $(0,76)$ & \\
\hline 6. Job satisfaction & 3,12 & 0,60 &, $268^{* *}$ &, 005 &, 119 &,- 089 &, 140 & $(0,85)$ \\
\hline
\end{tabular}

* Correlation is significant at the 0.05 level (2-tailed).

** Correlation is significant at the 0.01 level (2-tailed).

As shown in Table 2, as a result of Pearson correlation analysis caring had significant and positive relationships with job satisfaction $(r=, 268 ; \mathrm{p}<0.01)$. According to this finding $\mathrm{H}_{1}$ was supported. No significant relationships were found between other four dimensions of ethical climate such as law and code, rules, instrumental, and independence and job satisfaction. In this respect, $\mathrm{H}_{2}$, $\mathrm{H}_{3}, \mathrm{H}_{4}$ and $\mathrm{H}_{5}$ were not supported.

The regression analysis was carried out to determine the efficacy level of the perceptions of ethical climate types on job satisfaction. Multi-collinearity should be analyzed for a better regression model. In order to detect the presence of multi-collinearity, the tolerance and the variance inflation factors (VIFs) values (Akman et al., 2008: 108) are calculated. Small tolerance and high variance inflation factors (VIFs) values denote that there is a multi-collinearity 
The Effects of Ethical Climate Types on Job Satisfaction:

The Case of Tourism Industry

problem among independent variables (Kalayc1, 2009: 268). We can assume that multi-collinearity is not a problem in data since all significant variables in Table 3 have much higher tolerance values than 0.10 (Ozgener, Iraz, 2006: 1362) and have lower variance inflation factors (VIFs) than 5.0 (Bozic, 2007: 117).

Table 3. The Results of Regression Analysis for Job Satisfaction

\begin{tabular}{|c|c|c|c|c|c|c|}
\hline $\begin{array}{c}\text { Independent } \\
\text { variables }\end{array}$ & $\beta$ & S.E. & t-value & Sig. & Tolerans & VIF \\
\hline Caring & 0,201 & 0,068 & $2.974 *$ & $\mathbf{0 , 0 0 3} *$ & 0,825 & 1,212 \\
\hline Law and code & $-0,037$ & 0,046 & $-0,794$ & 0,429 & 0,891 & 1,122 \\
\hline Rules & 0,030 & 0,044 & 0,679 & 0,498 & 0,921 & 1,086 \\
\hline Instrumental & $-0,110$ & 0,074 & $-1,482$ & 0,140 & 0,929 & 1,076 \\
\hline Independence & 0,077 & 0,064 & 1,201 & 0,231 & 0,849 & 1,178 \\
\hline $\mathrm{F}$ & \multicolumn{6}{|c|}{3,390} \\
\hline Adjusted $\mathrm{R}^{2}$ & \multicolumn{6}{|c|}{0,068} \\
\hline & \multicolumn{6}{|c|}{0,096} \\
\hline $\begin{array}{l}\text { Std. Error of the } \\
\text { Estimate }\end{array}$ & \multicolumn{6}{|c|}{0,57963} \\
\hline Significance level & \multicolumn{6}{|c|}{0,006} \\
\hline
\end{tabular}

Dependent variable: Job satisfaction

$* \mathrm{p}<0,01$

The results of regression analysis in Table 3 suggest that the overall model was significant (Adjusted $\mathrm{R}^{2}=0,068 ; \mathrm{F}=3,390 ; \mathrm{p}<0,01$ ). The interrelation of five independent variables (caring, law and code, rules, instrumentalism and independence) was taken into account, and the $\mathrm{R}^{2}(0,096)$ was significant at the 0,01 level. This means that $9.6 \%$ of the variance in job satisfaction was significantly explained by the independent variables. Among independent variables, caring was found to be the most important in explaining the variance in job satisfaction as the highest beta value was 0,201 .

This research has pointed out that a positive and meaningful relationship between the perceptions of caring type of the ethical climate and the job satisfaction in hotel business as stated in previous research results and different sectors such as Kim and Miller (2008), Tsai and Huang 2008), Aydemir (2007), Mulki et al. (2006), Schminke et al. (2005), Schwepker Jr. and Hartline (2005), Suar and Khuntia (2004), Koh and Boo, (2001), Schwepker Jr. (2001) and the perceptions of caring type of the ethical climate could be the determinant factor over the job satisfaction of the hotel employees in Nevsehir. 
This study shows that an employee's preferred work climate most frequently indicates favor for a caring climate where organizations have a sincere interest in the well being of others inside and outside. In other words, concern for all organizational stakeholders was affected by firm's decisions.

In the final analysis, the role of ethical climate, specificaly caring climate should be taken into consideration in the implementations of business strategy, business objectives, and performance of a tourism or hospitality organizations. The interests of the organization will prevail over those of all stakeholders. Given the differences among stakeholders' interests, each one of them pays attention to whether theirs or other's interest are delivered fairly. Organizational ethical climate depends on procedural and distributive justice. Therefore, the real challenge for organization's management is to ensure and demonstrate that an organization's ethical climate is part of strategy implementations, business objectives, and organizational performance.

The following suggestions can be offered for ethical climate in order to increase job satisfaction level of hotel businesses staff:

- Public authorities should carry out necessary arrangements and provide an effective control mechanism in order to lead the organizations to form professional ethical codes.

- A comprehensive and joint ethical counsel should be founded in order to form professional codes, determine the standards, and supervise the applications.

- Higher administrative staff should be a model via their expressions and behaviors in the adaptation process of ethical behaviors for the whole staff.

- Human resources policies and applications, which have a crucial role in increasing job satisfaction, should be developed in accordance with the exemplary hotel business applications.

- Organizational socialization process should be provided in order that the employees can learn organizational policies, rules, norms, and procedures on an interactive basis.

- In-service training programs required for conveying the information about ethical codes and organizational values determined by the administration should be supplied. 
- Award and penalty system should be constituted and this system should be applied objectively.

Unless these issues are taken into account, turnover will increase, service quality will decrease, client satisfaction will be affected negatively, disadvantage of competition will occur, and consequently businesses will face the threat of withdrawing.

As a matter of fact, the findings of this study need to be interpreted with the following limitations in mind. First limitation is that the results cannot be strictly construed to be representative of all middle managers and employees in hotel businesses around the world, since this study has been conducted in a specific region of Turkey, Cappadocia. Therefore, the study needs to be replicated in different tourism destination, industries and countries to be able to generalize the findings. Second, participants may have been biased to present positive aspects of their businesses.

As stated this research aimed to investigate the relationship between ethical climate types and job satisfaction in hotel businesses. For the upcoming researches, it is possible to investigate the issue of ethical climate in different industry settings. Moreover, it would also be interesting to analyze the possible relationships between ethical climate and turnover intention, organizational citizenship behavior, psychological well-being for different industries or organizations.

\section{REFERENCES}

Akman, G., C. Ozkan, H. Eris (2008) "The Analysis of the the Effect of the Firm Performance by Using Strategic Focusing and the Firm Strategy", Istanbul Ticaret Universitesi Fen Bilimleri Dergisi, 7(13), 93-115.

Aydemir, M. (2007) "The Effects of the Satisfaction of Profession on the Ethical Climate in the Organizations", 15. Ulusal Yönetim ve Organizasyon Kongresi Bildiriler Kitabı, 25-27 Mayıs, Sakarya: Sakarya University, 848858.

Barnett, T., C. Vaicys (2000) "The Moderating Effect of Individuals' Perceptions of Ethical Work Climate on Ethical Judgments and Behavioral Intentions", Journal of Business Ethics, 27, 351-362.

Bartels, L.K., E. Harrick, K. Martell, D. Strickland (1998) "The Relationship Between Ethical Climate and Ethical Problems Within Human Resource Management", Journal of Business Ethics, 17, 799-804. 
Blaikie, N. (2001) Designing Social Research The Logic of Anticipation, Cambridge: Polity Press.

Bozic, L. (2007) “The Effects of Market Orientation on Product Innovation”, Croatian Economic Survey, 9, 107-124.

Buchko, A.A., L.G. Weinzimmer, A.V. Sergeyev (1998) "Effects of Cultural Context on the Antecedents, Correlates, and Consequences of Organizational Commitment: A Study of Russian Workers", Journal of Business Research, 43, 109-116.

Deshpande, S.P. (1996) "The Impact of Ethical Climate Types on Facets of Job Satisfaction: An Empirical Investigation”, Journal of Business Ethics, 15, 655-660.

Deshpande, S.P., E. George, J. Joseph (2000) "Ethical Climates and Managerial Succes in Russian Organizations", Journal of Business Ethics, 23, 211-217.

Elçi, M., L. Alpkan (2009) "The Impact of Perceived Organizational Ethical Climate on Work Satisfaction” Journal of Business Ethics, 84, 297-311.

Erben, G.S., A.B. Güneşer (2008) "The Relationship Between Paternalistic Leadership and Organizational Commitment: Investigating the Role of Climate Regarding Ethics”, Journal of Business Ethics, 82, 955-968.

Huberts, L.W.J.C., M. Jeroen, L.J. Carole (2008) "Global Perspectives on Good Governance Policies and Research", In Ethics and Integrity of Governance (Edited by L. W.J.C. Huberts, J. Maesschalck, C.L. Jurkiewicz), Massachhusetts USA: Edward Elgar.

Kalayc1, S. (2009) The Statistics Techniques in Spss Application and Multi Variables, Ankara: Asil.

Kaplan, M. (2010) "The Effect of the Perceived of The Ethical Climate and Organizational Support in Hotel Enterprises, The Example of Cappadocia", Unpublished Doctorate Dissertation, Selçuk University Social Science Institution., Konya, Turkey.

Kelley, S.W., M.J. Dorsch (1991) "Ethical Climate, Organizational Commitment and Indeptedness Among Purchasing Executives", Journal of Personel Selling and Sales Management, 11(4), 55-66.

Kim, N.Y., G. Miller (2008) "Perceptions of the Ethical Climate in the Korean Tourism Industry”, Journal of Business Ethics, 82, 941-954. 
Koh, H.C., E.H.Y. Boo (2001) "The Link Between Organizational Ethics and Job Satisfaction: A Study of Managers in Singapore", Journal of Business Ethics, 29, 309-324.

Kusluvan, S., Z. Kusluvan, I İlhan, L. Buyruk (2010) “The Human Dimension: A Review of Human Resources Management Issues in the Tourism and Hospitality Industry”, Cornell Hospitality Quarterly, 51(2), 171-214.

Kusluvan, Z., S. Kusluvan (2003) "The Relative Effects of Factors Related with the Occupation and the Enterprise, The Example of Nevsehir", Anatolia: Journal of Tourism Researches, 16(2), 183-203.

Lewin, A.Y., T. Sakano, C.U. Stephens, B. Victor (1995) "Corporate Citizenship in Japan: Survey Results from Japanese firms”, Journal of Business Ethics, 14, 83-101.

Lopez, T.B., B.J. Babin, C. Chung (2009) "Perceptions of Ethical Work Climate and Person-Organization Fit Among Retail Employees in Japan and the US: A Cross-Cultural Scale Validation”, Journal of Business Research, 62, 594-600.

Martin, K.D., J.B. Cullen (2006) "Continuities and Extensions of Ethical Climate Theory: A meta-Analytic Review”, Journal of Business Ethics, 69, 175-194.

Mulki, J.P., F. Jaramillo, W.B. Locander (2006) "Effects of Ethical Climate and Supervisory Trust on Salesperson's Job Attitudes and Intentions to Quit", Journal of Personall Selling \& Sales Management, XXVI(1), 19-26.

Nunnally, J. (1978) Psychometric Theory, New York: Mc Graw-Hill.

Ogut, A., M. Kaplan (2010) "The Relationship between Perceptions of Ethical Climate Types and Affective Commitment: The Case of Turkish Hotel Employees", 6th International Strategic Management Conference (St. Petersburg, Russia, July 8-10), 893-900.

Özgener, S., R. Iraz (2006) "Customer Relationship Management in Small-Medium Enterprises: The Case of Turkish Tourism Industry", Tourism Management, 27, 1356-1363.

Rasmussen, K., D. Malloy, J. Agarwal (2003) "The Ethical Climate of Government and Non-Profit Organizations Implicants For Public-Private Partnerships”, Public Management Review, 5(1), 83-97.

Ruppel, C.P., S.J. Harrington (2000) "The Relationship of Communication, Ethical Work Climate, and Trust to Commitment and Innovation", Journal of Business Ethics, 25, 313-328. 
Schminke, M., M.L. Ambrose, D.O. Neubaum (2005) "The Effect of Leader Moral Development on Ethical Climate and Employee Attitudes", Organizational Behavior and Human Decision Processes, 97, 135-151.

Schwepker Jr, C.H. (2001) "Ethical Climate's Relationship to Job Satisfaction, Organizational Commitment, and Turnover Intention in the Saleforce", Journal of Business Research, 54, 39-52.

Schwepker Jr, C.H., M.D. Hartline (2005) "Managing the Ethical Climate of CustomerContact Service Employees”, Journal of Service Research, 7(4), 377-397.

Sekaran, U. (2003) Research Methods for Business: A Skill-Building Approach, Fourth Edition, New York: John Wiley and Sons.

Shapira-Lishchinsky, O., Z. Rosenblatt (2009) "Perceptions of Organizational Ethics as Predictors of Work Absence: A Test of Alternative Absence Measures", Journal of Business Ethics, 88, 717-734.

Suar, D., R. Khuntia (2004) "Does Ethical Climate Influence Unethical Practices and Work Behavior", Journal of Human Values, 10(1), 11-21.

Trevino, L.K., A. Nelson Katherine (2004) Managing Business Ethics: Straight Talk About How to do It Right, Hoboken: John Wiley \& Sons, Inc.

Tsai, M.T., C.C. Huang (2008) “The Relationship Among Ethical Climate Types, Facets of Job Satisfaction, and the Three Components of Organizational Commitment: A Study of Nurses in Taiwan", Journal of Business Ethics, 80, 565-581.

Vandenabeele, W. (2009) "The Mediating Effect of Job Satisfaction and Organizational Commitment on Self-Reported Performance: More Robust Evidence of the Psm-Performance Relationship", International Review of the Administrative Sciences, 75(1), 11-34.

Victor, B., J.B. Cullen (1988) "The Organizational Bases of Ethical Climates", Administrative Science Quarterly, 33, 101-125.

Weber, J. (1995) "Influences Upon Organizational Ethical Subclimates: A MultiDepartmental Analysis of A Single Firm”, Organizational Science, 6(5), 509. 523.

Weber, J., J.E. Seger (2002) "Influences Upon Organizational Ethical Subclimates: A Replication Study of a Single firm at two Points in Time", Journal of Business Ethics, 41, 69-84. 
The Effects of Ethical Climate Types on Job Satisfaction:

The Case of Tourism Industry

Weeks, W.A., T.W. Loe, L.B. Chonko, K. Wakefield (2004) “The Effects of Perceived Ethical Climate on the Search for Sales Force Excellence", Journal of Personel Selling and Sales Management, XXIV(3), 199-214.

Wimbush, J.C., J.M. Shepard, S.E. Markham (1997) “An Empirical Examination of the Multi-Dimensionality of Ethical Climate in Organizations", Journal of Business Ethics, 16, 67-77.

Wyld, D.C., C.A. Jones (1997) “The Importance of Context: The Ethical Work Climate Construct and Models of Ethical Decision Making-an Agenda for Research", Journal of Business Ethics, 16, 465-472. 